\title{
Chinese MNEs and Managerial Knowledge Transfer to Africa: The Case of the Construction Sector in Ghana
}

\begin{abstract}
:
This paper examines managerial knowledge transfer from Chinese multinational enterprises in Africa, in the context of the Ghanaian construction sector. Using empirical data from in-depth qualitative interviews and by comparing Chinese MNEs to western MNEs, the paper investigates key channels as well as determinants and impediments of managerial knowledge spillovers in this sector. It finds that managerial knowledge transfer from Chinese MNEs in the construction section is constrained by limited local employment at the managerial level in Chinese construction firms, as well as cultural and linguistic barriers. Localisation strategies, in which Chinese managers are progressively replaced by local ones, are found to emerge in Chinese MNEs. This helps to overcome these barriers, foster managerial knowledge spillovers, and ensure these MNEs' sustainability in Africa.
\end{abstract}

JEL classifications: $\mathrm{O} 14, \mathrm{O} 19, \mathrm{O} 33$

Keywords: foreign direct investment, knowledge spillovers, management, China, Africa 
Foreign direct investment (FDI) has long been recognised as a potential driver of economic growth in developing countries (Moran et al. 2005). Multinational entreprises (MNEs), firms that operate in more than one country, are the main sources of FDI $^{1}$ (Dunning 1994). Potential benefits of FDI for the host economy include an inflow of capital, job creation, and most importantly knowledge spillovers. Spillovers occur when the MNE cannot fully internalise its stock of knowledge (which embeds technology and management practices), and domestic companies are able to make use of it (Crespo and Fontoura 2007). Theoretically, knowledge spillovers can increase domestic productivity, foster economic growth and ultimately lead to poverty alleviation in developing countries (UN 2002). Managerial knowledge spillovers, which specifically refer to the adoption of foreign management practices by domestic firms as a consequence of FDI, have been understudied in the literature, despite a rising recognition of the role of management practices in increasing productivity ( $\mathrm{Fu} 2012 \mathrm{~b}$ ).

Academic research initially assumed that FDI spillovers were unproblematic (Lall 1992), but empirical findings suggest that they are determined by a number of factors, including the source country of the investment (Crespo and Fontoura 2007). In particular, increasing FDI from emerging economies has led some to suggest that this type of FDI could be more prone to spill over knowledge in other developing countries than is FDI from developed economies (Fu and Gong 2011). This debate takes place in the context of deepening economic relations between China and Africa. Indeed, the past decade has witnessed a radical transformation of China-Africa relations. While Sino-African trade has increased more than tenfold over the period 2000-2010, turning China into Africa's biggest trade partner (Ayenagbo et al. 2012), Chinese FDI to Africa accounted for over US\$2 billion in 2010 - a 565\% increase since 2004 (MOFCOM 2011). This rapid evolution has raised widespread media attention, and generated both hope and fear. Research is lagging behind to analyse this fast-changing phenomenon. Though multiple authors have looked at the specificities of Chinese FDI in Africa, the question of knowledge spillovers from Chinese FDI is yet to be considered. This paper attempts to fill this gap using a qualitative methodology that is well-adapted to under-researched topics and to the study of management systems. The research is based on a case study of the Ghanaian construction sector, which has attracted large amounts of Chinese FDI in the last decade.

Research findings suggest that managerial knowledge spillovers from Chinese construction firms, in the Ghanaian context, are restricted by the lack of local employees at the managerial level. This is the result of complex cultural, linguistic, historical and economic dynamics. However, a number of Chinese contractors in Ghana are making concrete attempts to localise their managerial workforce. This localisation process, which is just beginning, could not only increase the capacity of Chinese firms to transfer managerial knowledge, but also significantly enhance their contribution to local

${ }^{1}$ MNEs are also referred to as multinational corporations (MNCs) or transnational corporations (TNCs). 
development in Africa.

The paper is organised as follows. Section 2 places the research within the existing literature on knowledge spillovers from FDI and Chinese investments in Africa. Section 3 exposes briefly the methodology of the research. Section 4 analyses the channels and determinants of managerial knowledge spillovers from FDI in the Ghanaian construction sector. Section 5 then considers the case of Chinese contractors. It details the cultural, linguistic, historical and economic factors impeding on the recruitment of locals at the managerial level in Chinese construction firms, which ultimately restrict managerial knowledge spillovers. Finally, section 6 discusses the emergence of localisation strategies in Chinese construction companies based on the case of a Chinese contractor in Ghana. Section 7 concludes.

\section{Literature review and theoretical framework}

\subsection{Knowledge spillovers from FDI}

MNEs face a number of difficulties when investing abroad - for instance, linguistic issues, cultural distance or unfamiliarity with the local market (Lall and Streeten 1977). For their foreign investments to be profitable, MNEs must therefore possess a substantial advantage over their local competitors, e.g. a cheaper access to capital, advanced management skills or new technology (ibid.). With the shift to a knowledge-based economy in the $21^{\text {st }}$ century, managerial and technological capacities are now the main assets of MNEs (Powell and Snellman 2004). When MNEs invest abroad, they are not always able to fully internalise their stock of knowledge and domestic firms can then benefit from these assets: this is a knowledge spillover (Crespo and Fontoura 2007). Demonstration effects are perhaps the most obvious spillover channel: domestic firms can observe new practices and techniques in MNEs and reproduce those they perceive as productive (Blomström and Kokko 1998; Crespo and Fontoura 2007). Local firms interacting with the MNE (suppliers, subcontractors, clients) are the most likely to benefit from demonstration effects (Lall 1980). Labour mobility, domestic firms employing workers trained by the MNE, is a second possible channel (Motta 1999). Finally, knowledge may also circulate through informal social networks by word of mouth (Inkpen and Tsang 2005; Fu 2012b).

The empirical evidence of knowledge spillovers from FDI is, "at best", mixed (Görg and Greenaway 2004:171), and suggests they are highly dependent on the investment context. There is strong evidence that absorptive capacity, understood as the level of human capital in the FDI-recipient country, is a positive determinant of spillovers (e.g. Girma and Görg 2003; Durham 2004; Fu 2008). Host-country institutions and policies also impact knowledge spillovers, although there are considerable debates on which are most suitable. The source country of FDI can affect its potential for knowledge spillovers. For instance, Keller (2001) shows that knowledge spillovers decrease with the geographic distance between source and host countries. This is due to increasing costs of communication between headquarters and subsidiaries, but can also be a consequence of cultural and linguistic distance. Others argue that cultural distance could actually favour knowledge spillovers by exposing domestic firms to more diversity (Rodriguez-Clare 
1996; Zhang et al. 2010).

Finally, the level and type of knowledge embedded in the investment determine significantly the extent of spillovers. The literature emphasises the importance of the "technological gap" between MNEs and local firms (Findlay 1978; Wang and Blomström 1992; Kokko 1994). If the knowledge of the MNE is too far ahead or too close to that of domestic firms, spillovers risk not taking place: either domestic firms will lack the ability to assimilate foreign knowledge, or the amount of knowledge they will be able to grasp will be insignificant for productivity improvements. This argument is close to the "appropriate technology" (AT) theory. The AT hypothesis argues that technology from developed countries might only lead to limited productivity gains in developing countries because it would not match their specific endowments in skills, labour and capital. Appropriate technology fits the socio-economic characteristics and the technological level of the recipient country (Stewart 1983; Willoughby 1990; Fu et al. 2011). Following this argument, MNEs from emerging economies, such as China, could bring more appropriate technology to other developing countries (Fu and Gong 2011; Fu 2012a).

Managerial knowledge tends to be overlooked in the literature on knowledge spillovers from FDI. Yet, just as technology, management practices can have a significant impact on a firm's productivity (Fu et al. 2007). The elusive nature of managerial knowledge may explain this lack of research. Indeed, managerial knowledge includes both tacit and explicit components. One the one hand, tacit knowledge, "that which we know but cannot tell" (Polanyi 1967) refers to the subconscious mechanisms that are used by managers to guide their decisions. Tacit knowledge builds on the socio-cultural context and on previous experiences (Ancori et al. 2000; Smith 2001). Because tacit knowledge is intrinsically individual, it is difficult to formalise and communicate. On the other hand, explicit knowledge consists in identifiable rules of action that are easy to translate into formal language (ibid.). These two categories of knowledge do not have set boundaries. Tacit knowledge can be made explicit through a codification process (Ancori et al. 2000). Codification facilitates knowledge flows within the MNE, and increases the likelihood of knowledge spillovers - codified knowledge is easier to identify and replicate than tacit knowledge (ibid.). Fu (2012b) provides the first systematic analysis of managerial knowledge spillovers from FDI. She concludes that despite having similar channels and determinants to technological knowledge spillovers, managerial knowledge spillovers bear their own characteristics. In particular, she highlights the importance of cultural distance and local context for managerial knowledge spillovers.

\subsection{Chinese investments in Africa}

China-Africa relations have changed considerably over the past decade. After the opening of the Chinese economy (1978) and the progressive reforms of Chinese stateowned enterprises (SOEs) in the late 1990s, the "Go Out" policy ${ }^{2}$ launched in 1999 encouraged Chinese firms to invest abroad to acquire skills, technology and experience (Buckley et al. 2007). As a result of this active foreign policy, Chinese FDI in Africa

\footnotetext{
${ }^{2}$ In Chinese 走出去 (Ž̌uchūqū). Also referred to as the "Go Global” policy.
} 
soared over the last decade. From 2004 to 2010 alone, Chinese investments in Africa jumped from US\$317 million to US\$2.1 billion (MOFCOM 2011) ${ }^{3}$. It is important to highlight that Chinese FDI to Africa, both in terms of flows and stock, is still small compared to FDI from developed economies (Allix 2013). This boom in Chinese FDI to Africa has led to dramatic assessments: China is alternatively cast as a neocolonial power (Jauch 2011) or as the ultimate solution to Africa's woes (Moyo 2012).

A recurrent observation in the literature is that Chinese investments in Africa are somehow distinctive from "traditional" investments from Western countries (Haglund 2009; Sautman and Yan 2009; Kaplinsky and Morris 2009). The differences identified are partly due to the predominance of SOEs within Chinese investors, though there is a growing number of private Chinese firms investing in Africa (Kaplinsky et al. 2007; Kaplinsky and Morris 2009; Gu 2009). Kaplinsky et al. (2007) argue that Chinese FDI is more long-term oriented because Chinese SOEs are not subjected to the same short-term profit maximising imperatives as their competitors. For the same reason, Chinese FDI is also supposed to be less risk-averse (Tull 2006; Kaplinsky and Morris 2009). However, quantitative studies do not support this argument, and suggest that Chinese FDI is rather cautious and selective (Biggeri and Sanfilippo 2009; Sanfilippo 2010). Other findings show that Chinese firms in Africa tend to be significantly younger and less productive (in terms of value per worker) than their competitors (Henley et al. 2008). There is also a debate around the level of local content used by Chinese firms in Africa. Burke and Corkin (2006) and Alden and Davies (2006) argue that Chinese FDI is characterised by low levels of local content and a limited use of local labour. Yet, Sanfilippo (2010) and $\mathrm{Fu}$ (2012a) find that Chinese FDI in Africa is more labour-intensive and leads to significant job creation, especially for low-skilled labourers. Finally, some of the literature points to tense labour relations between local workers and management teams, which are almost exclusively Chinese (Gu 2009; Haglund 2009; Lee 2009; Jauch 2011). These tensions seem to arise from the limited foreign language skills of Chinese expatriates and from a wide cultural gap between Chinese and Africans (ibid.).

\subsection{Studying managerial knowledge spillovers from Chinese FDI in Africa}

Considering the existing literature, we can then distinguish several characteristics of Chinese FDI in Africa which may affect managerial knowledge spillovers. The extent of local linkages developed by Chinese MNEs in Africa will affect demonstration effects and voluntary knowledge-sharing mechanisms. If Chinese MNEs are indeed characterised by limited local linkages, domestic firms will not have the opportunity to learn from their management practices. Furthermore, the integration of local labour

\footnotetext{
${ }^{3}$ Caution is recommended with FDI statistics. Pietrobelli et al. (2010:3) noted that the MOFCOM FDI statistics "underestimate the real value of investments because they do not include the financial sector and are based on the value arising from approval procedures rather than the effective value of bids ... In addition, these data do not account for most M\&A activity ... Notwithstanding these limitations, MOFCOM data represent the most up-to-date source of information on Chinese FDI, disaggregated by destination country and sector".
} 
within Chinese MNEs will affect spillovers through labour mobility and social networks. This is not only about the number of locals employed in Chinese firms, but also about the positions in which they are employed: managers are more likely to be in a position to assimilate foreign managerial knowledge and to circulate it within their networks. Moreover, the extent to which managerial knowledge is codified within Chinese MNEs will determine the relative importance of the different channels of managerial knowledge spillovers. If knowledge codification is extensive, demonstration effects and social networks are likely to be effective channels of spillovers. If managerial knowledge in Chinese MNEs is mostly tacit, voluntary knowledge sharing and use of local labour will be the most important channels of transmission. Additionally, as the substantial part of tacit knowledge within managerial knowledge implies that good personal interactions are essential to foster spillovers, cross-cultural management difficulties and poor labour relations in Chinese firms could impede managerial knowledge spillovers.

A last point to consider is the "knowledge gap" between Chinese MNEs and African firms and the appropriateness of Chinese management practices for the local context. Because of their shorter experience on the international scene, the management system of Chinese MNEs is likely to be less mature than the one of Western MNEs. This could impact managerial knowledge spillovers positively (management practices could be easier to identify and reproduce) or negatively (the amount of managerial knowledge available could simply be insignificant for domestic firms). In terms of knowledge appropriateness, previous research has shown that Chinese MNEs have more labourintensive practices (Sanfilippo 2010; Fu 2012a). This could indicate management systems better adapted to developing country contexts, building on large quantities of low-skilled labour. However, managerial knowledge always incorporates socio-cultural elements. It is possible that the cultural foundations of Chinese management practices clash with African cultural values, making Chinese managerial knowledge inappropriate in African contexts.

\section{$3 \quad$ Research methodology}

\subsection{A qualitative case study}

The research favoured a case study approach, which is well adapted to the study of underresearched topics, as in the present case. The focus of the study on managerial knowledge, which entails a strong focus on human interaction and the consideration of sociocultural variables, called for the use of qualitative methods rather than quantitative ones. The case of the Ghanaian construction sector was selected in the hope that it would constitute an exemplifying case for other sectors and countries receiving Chinese FDI across Africa. Nonetheless, the results presented in this paper need to be understood as contextually bounded.

The choice of Ghana was motivated by the dynamism of its economy and its rising attractiveness for foreign investors, most notably Chinese. Chinese FDI outflows to Ghana have soared from less than US\$1 million in 2006 to over US\$55 million in 2010, 
and Ghana was the ninth largest African recipient of Chinese FDI in 2010 (MOFCOM 2011). Over the period 2008-2010, China was the first foreign investor in Ghana in terms of number of projects and the eight in terms of value of projects (Sutton and Kpentey 2012). The study was further focused on the construction sector, based on its importance in the Ghanaian economy - construction has been the fastest growing industry over the period 2000-2009, observing an 88\% growth (Sutton and Kpentey 2012) - and its relatively large FDI inflows (construction received 33.6\% of total FDI inflows to Ghana over the 2008-2010 period (ibid.)). Moreover, while Chinese FDI to Africa remains low in comparison to European or American FDI inflows (Allix 2013), the situation varies considerably between sectors: China's share of the African construction market reached $36.6 \%$ in 2010 (Van Valen 2012). This trend is observable in Ghana, where multiple Chinese firms are challenging long-term traditional investors from the West (Sutton and Kpentey 2012).

\subsection{Data collection and analysis}

Fieldwork research comprised of 10 weeks in Ghana over the period July-August 2013. Semi-structured, in-depth interviews were the main tool of qualitative data collection. Participants were selected through both theoretical and snow-ball sampling.

A total of 31 interviews involving 39 participants were realised (seven interviews involved more than one participant). All interviews took place in Accra. The interviews lasted from 30 minutes-one-and-a-half hour and were conducted in English and, in one case, in French. Interview questions followed general themes and were adapted to the position of the participant(s), with a flexible structure allowing for reactions to the interviewee's answers and comments. Interviewees included a variety of actors in and out of the construction sector, such as managers and employees in Western and Chinese construction firms, suppliers, subcontractors and consultants to construction firms, civil servants in ministries and government agencies, employees of international development agencies, academics and other relevant stakeholders. This diversity was essential to triangulate the data collected. Table 1 presents a breakdown of respondents per occupation and nationality. 
Tab. 1: Breakdown of respondents by nationality and occupation

\begin{tabular}{|c|c|c|c|c|}
\hline Participants & African $^{4}$ & Chinese & Western $^{5}$ & Total \\
\hline $\begin{array}{l}\text { Construction } \\
\text { companies }\end{array}$ & 4 & 4 & 3 & $11(28.2 \%)$ \\
\hline $\begin{array}{l}\text { Other private sector } \\
\text { International } \\
\text { development agencies }\end{array}$ & $\begin{array}{l}7 \\
5\end{array}$ & $\begin{array}{l}0 \\
0\end{array}$ & $\begin{array}{l}0 \\
2\end{array}$ & $\begin{array}{l}7(17.9 \%) \\
7(17.9 \%)\end{array}$ \\
\hline $\begin{array}{l}\text { Ministries and } \\
\text { government agencies }\end{array}$ & 6 & 0 & 0 & $6(15.4 \%)$ \\
\hline Civil society $^{7}$ & 6 & 2 & 0 & $8(20.5 \%)$ \\
\hline Total & $28(71.8 \%)$ & $6(15.4 \%)$ & $5(12.8 \%)$ & $39(100 \%)$ \\
\hline
\end{tabular}

In addition to interviews, qualitative data was collected during and after the fieldwork period in various sources of grey literature: Ghanaian and international media, websites and reports of local and international organisations, and companies' press releases and annual reports. A limited amount of quantitative and qualitative data were also collected through interviewees (e.g. unpublished reports, statistics).

Data analysis followed the general principles of grounded theory for case study theorybuilding (Glaser and Strauss, 1967; Eisenhardt 1989). Data analysis was not separated from data collection, but rather conducted simultaneously as part of a reflexive and inductive process. The analysis relied partly on simple coding techniques to identify themes in the data. Theories developed from the empirical data were strengthened through a systematic comparison with existing literature (both conflicting and supporting). This triangulation process was instrumental to raise the theoretical level of the analysis, and to address validity concerns.

\subsection{Methodological limitations}

The findings presented in this paper may present several biases. My age, race and gender (young, white, female) may have affected the responses of participants as well as my own interpretation of these responses. Being neither African nor Chinese may have been an advantage - African participants spoke candidly about Chinese firms, and Chinese participants gave honest accounts of their experiences in Ghana. However, it may also have biased opinions expressed about Western construction companies.

4 Most African respondents were Ghanaians, with two exceptions (nationals of neighbouring countries).

5 Western nationalities are understood broadly and regroup all European respondents.

6 "Other private sector" interviews included consultancies, suppliers and subcontractors to the construction sector.

7 Civil society includes academics, trade unions, and professional associations. 
Two further types of biases may have affected data collection. Firstly, several firms (Chinese and Western) declined interviews. It may be that only firms with best practices in terms of training, local labour and relations with local stakeholders agreed to participate (non-response bias). Secondly, participants may have biased their answers to be perceived positively, for instance, exaggerating the importance of their training programmes or their commitment to local employment (response bias). Whenever possible, data was triangulated from different sources to mitigate the effects of these biases.

\section{$4 \quad$ Managerial knowledge spillovers in the Ghanaian construction sector}

\subsection{Overview of the Ghanaian construction sector}

Before highlighting the main channels and determinants of managerial knowledge spillovers in the Ghanaian construction sector, a few remarks are necessary to understand the underlying dynamics of the sector and the main issues faced by domestic firms.

The Government of Ghana (GoG) is the largest client of the construction industry. Most public construction projects are submitted to national (domestic contractors only) or international (open to foreign firms) competitive tendering. Projects are supervised by specialised government agencies, such as the Ghana Highway Authority (GHA), the Department of Urban Roads (DUR) or the Department of Rural Housing (DRH). Multilateral and bilateral development organisations can provide project funding to government agencies, either as loans or grants. Construction projects usually involve a cooperation between a consultant, in charge of the project design and day-to-day supervision, and a main contractor, who may subcontract parts of the contract to smaller companies.

There is a large number of domestic contractors in Ghana, but apart from a few exceptions, they are generally small firms (Vulink 2004). Most belong to one of two professional associations, the Association of Building and Civil Engineering Contractors of Ghana (ABCECG) and the Association of Road Contractors in Ghana (ASROC), which undertake information and advocacy campaigns and provide training sessions to their members. There is a general capacity issue in Ghanaian construction firms, characterised by a lack of access to capital due to high interest rates, which in turn prevents the necessary investments in technical equipment and skilled labour that would create sustainable company growth. Financing issues are complicated by regular delays in government payments: as the majority of projects are government projects, constant delays induce severe cash flow issues for domestic contractors. Several respondents pointed out the lack of managerial know-how of domestic construction firms' owners, highlighting poor contract management skills and their inability to delegate tasks and retain qualified workers. The predicament of domestic contractors is a vicious circle: with little access to capital and qualified workers, they cannot compete with international firms on large-scale projects, which limits them to small-budget government works that pay with delays, and ultimately hinders their access to capital and their ability to retain 
qualified employees.

Foreign firms dominate the construction project, realising the biggest (and most profitable) projects. Foreign construction firms vary widely in terms of size, type of works undertaken, length of implantation in Ghana, ownership structure and origins. There is a small group of well-implanted foreign contractors (mostly European), which is being challenged by a growing number of Chinese firms (Sutton and Kpentey 2012). It is important to note that the Chinese contractors do not form a homogeneous group, especially in terms of ownership structure (they can be central-state SOEs, provincialstate SOEs, or have mixed public-private ownership structures). Foreign-local joint ventures or partnerships are rare, partly because of the local capacity issues outlined above.

It is important to note that employment of foreign nationals in Ghana is restricted. Foreign companies have a quota of visas for foreign employees, which depends on the amount of paid-up capital they invest in Ghana (Tab. 2). A foreign company may apply for more visas than its quota allows for, but has to justify why it needs to bring in foreign expertise. The effectiveness of these measures is limited by the enforcing capacity of the government. Nonetheless, two foreign participants noted that restrictions on foreign employment had become tougher in recent years, and that the GoG has progressively raised the level of skills required to justify the attribution of extra working visas.

Tab. 2: Visa quotas for foreign investors

\begin{tabular}{|c|c|} 
Value of investment & Working visas authorised \\
Under $\$ 100,000$ & 1 \\
$\$ 100,000$ to $\$ 500,000$ & 2 \\
$\$ 500,000$ and more & 4 \\
\hline
\end{tabular}

\subsection{Key channels of managerial knowledge spillovers}

Based on the theoretical framework, the research identified five potential beneficiaries of managerial knowledge spillovers in the construction sector: employees, subcontractors, suppliers, competitors and construction consultancies.

\section{Employees}

Because of their direct integration in the MNEs' management systems, Ghanaian employees in foreign construction firms are the primary recipients of foreign managerial knowledge. Interviews with foreign contractors highlighted three vectors of managerial learning: experience (1), formal training (2), and mentorship (3). 


\section{(1) Experience}

Locals employed in managerial positions in foreign companies accumulate foreign managerial knowledge through observation and experience. As foreign companies undertake the biggest contracts in Ghana, their local managers have the opportunity to be exposed to complex projects involving large budgets and tough time and quality constraints, and to the correspondingly advanced management practices. Employees in non-managerial positions also have limited learning opportunities through observation and interaction - they are also included in a foreign management system - but how much knowledge they will be able to assimilate and reuse will depend on their prior experience and education, as well as on the time they spend with the foreign contractor.

\section{(2) Formal training}

Local managers in foreign construction firms can also benefit from a more active form of managerial knowledge transfers through formal training programmes. Most foreign companies interviewed reported having training sessions for their local managers. Training contents are usually tailored to the development level of the employee and target specific skill gaps. Examples of training modules included time, quality and cost management, as well as more general sessions on project management. Training locations vary, sessions can be internal to the company and conducted by local employees' own foreign managers, or delegated to an external consultancy. MNEs may also send their local employees abroad for training.

\section{(3) Mentorship}

Mentorship can be defined as a formal or informal dyadic relationship between a foreign senior manager (the "mentor") and a more junior local employee working for the same company. Mentorship supposes the development of a long-term professional relationship between two individuals, with the implicit purpose of building the capacity of the local employee. Among the six companies interviewed for this research, only one indicated having a formal mentorship scheme, but in at least one other foreign firm, interviews revealed the existence of similar dyadic relationships, though at a more informal level.

\section{Suppliers}

Local suppliers' managerial capacity may also improve as a consequence of foreign contractors' activities. In this case, the most important element seems to be the development of a long-term business relationship involving multiple interactions between the supplier and the foreign contractor. A long-term relationship with frequent interactions creates a pressure on the supplier to upgrade its services to keep clients satisfied. Foreign contractors generally observed an improvement over time in the services of their regular suppliers, such as more timely deliveries and better quality of products purchased. Though this pressure to upgrade, or disciplining factor, is not exactly a managerial knowledge spillover (the supplier is not necessarily adopting the practices of the foreign firm), it is an efficient driver for managerial capacity building in suppliers. Additionally, a long-term business relationship with a foreign contractor can be a factor 
of financial stability for local suppliers. Regular cash entries can provide an opportunity for a local company to expand and upgrade its management system. Finally, in terms of training, only one foreign contractor mentioned organising formal training sessions for its suppliers, though others indicated providing suppliers with more informal guidance.

The extent of these positive externalities remains limited. Given the low development of the Ghanaian manufacturing sector, local suppliers are often import companies: they are generally small in size and may simply not have the space or the need for a more complex management system.

\section{Subcontractors}

The dynamics of managerial knowledge spillovers for local subcontractors are similar to those of suppliers. Again, the development of a long-term business relationship is essential to an upgrading of subcontractors' managerial capabilities, and most contractors noted an amelioration of subcontractors' services over the time of their collaboration. Given the high turnover in subcontractors (the type of works subcontracted varies from project to project), the incentive for foreign contractors to provide them with managerial training is low.

However, subcontractors have more opportunities than suppliers for learning through observation of the contractor's management practices. Indeed, subcontractors work on site for the duration of their contract, often under the direct supervision of the foreign contractor's project manager. Additionally, subcontractors are more likely than suppliers to pick up new managerial practices, as the core of their work is more closely related to that of the contractor's.

\section{Competitors}

Local competitors can theoretically benefit from knowledge spillovers, through pressures to upgrade, demonstration effects and labour mobility (Cheung and Lin 2004). Fieldwork findings were inconclusive in that regard - time and budget constraints did not allow for a thorough examination of the sources of managerial knowledge for local construction companies. Nonetheless, a few careful hypotheses can be suggested. Firstly, local and foreign contractors do not seem to compete on the same level: local contractors bid on smaller contracts reserved to Ghanaian companies, while foreign contractors have a de facto monopoly on larger works. Direct observation of foreign competitors is therefore limited. Secondly, the capacity gap between foreign and domestic contractors might be too wide for efficient knowledge spillovers through demonstration effects. The management systems used by foreign companies might simply be inappropriate for smaller local firms. Finally, labour mobility could be strongly limited by budget constraints: local contractors might not be able to afford foreign-trained employees.

\section{Construction consultancies}

The specific case of construction consultancies is interesting. These firms do not categorise as local linkages - they are usually brought in by the client rather than the 
contractor; they also do not qualify as local competitors to foreign contractors. However, the research highlighted possible managerial knowledge spillovers from foreign construction firms to local construction consultancies through labour mobility. Whereas domestic contractors' development is constrained by a lack of access to finance, consultancies can be set up more easily and require a lower start-up capital. Technical experts (e.g. civil engineers, quantity surveyors) exposed to advanced management practices in foreign construction firms are therefore in an ideal position to start or join a local consultancy firm.

Figure 1 summarises the different channels of managerial knowledge spillovers in the Ghanaian construction sector, emphasising the most effective ones.

Fig. 1: Channels of managerial knowledge spillovers in the Ghanaian construction sector

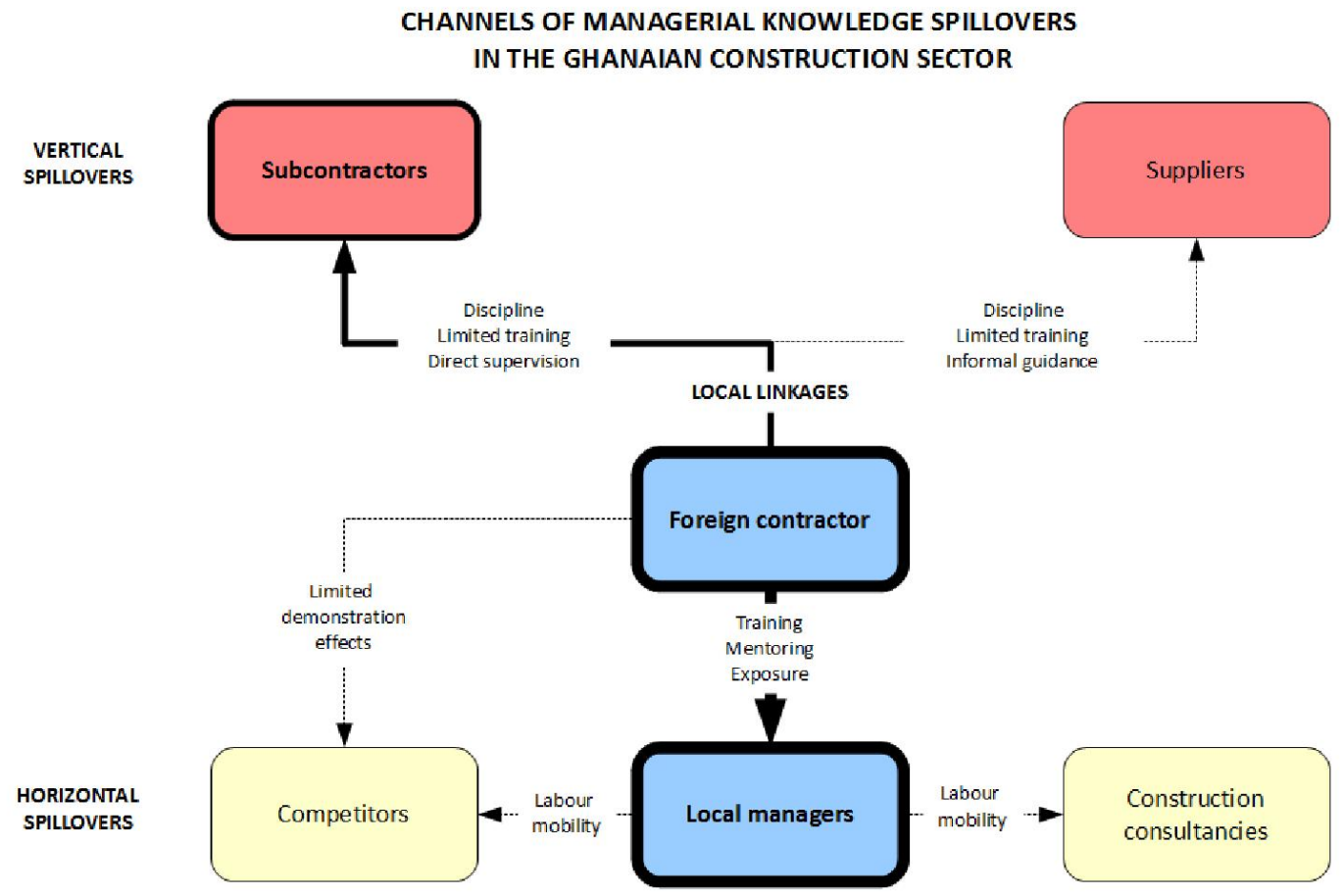

\subsection{Key determinants of managerial knowledge spillovers}

\section{Absorptive capacity}

Educational achievement rates are high in Ghana compared to other Sub-Saharan African countries, and they have been improving rapidly. But they remain low, and as a labour- 
intensive industry, the construction sector attracts many more unskilled workers than university-educated ones. Assuming that knowledge spillovers can only impact individuals over a certain threshold of human capital $^{8}$, it is likely that they will be restricted to the most educated individuals interacting with the foreign entity. In addition to the limited labour mobility from foreign to domestic firms, this implies that the broader impact of those managerial knowledge spillovers on domestic productivity could very well be insignificant in absolute terms.

\section{Tacit knowledge and the central role of personal interactions}

Research findings suggest that tacit knowledge is particularly present in the construction sector, with exposure and mentorship being two key ways of transferring managerial knowledge onto local employees. This makes interpersonal and cross-cultural relationships within the foreign company a strong determinant of managerial knowledge spillovers. Frequent and fluid communication, as well as cross-cultural understanding, appear to be important elements favouring knowledge spillovers. This means the extent of managerial knowledge spillovers will vary depending on the quality of the learning environment within the foreign construction firm and on the personalities of the individuals involved.

\section{Structural constraints to further transfers}

Finally, some of the structural features of the Ghanaian construction sector limit the extent of managerial knowledge spillovers. For instance, labour mobility from foreign to local contractors is constrained: local managers trained in foreign companies are a scarce resource, and local contractors can rarely afford poaching them. Limited access to capital also means that foreign-trained managers wishing to start their own firm may not be able to expand their companies and to transfer their managerial knowledge onto their own employees. Construction consultancies do not face the same structural constraints, and could be more successful at keeping the managerial knowledge acquired alive.

Based on the analysis of sections 4.2 and 4.3, Table 3 presents a summary of determinants of managerial knowledge spillovers in the Ghanaian construction sector, for each of the potential knowledge recipients.

8

This assumption has been tested successfully at the firm (Girma 2005) and country levels (Falvey et al. 2007), with absorptive capacity measured in terms of R\&D investments (rather than human capital). 
Tab. 3: Determinants of managerial knowledge spillovers in the Ghanaian construction sector for selected recipients

\begin{tabular}{|c|c|}
\hline Recipient & Determinants of managerial knowledge spillovers \\
\hline $\begin{array}{l}\text { Ghanaians } \\
\text { employed in foreign } \\
\text { construction firms }\end{array}$ & $\begin{array}{l}\text { - Absorptive capacity } \\
\text { - Quality of communication with foreign managers } \\
\text { - } \text { Quality of interpersonal relationships with foreign managers } \\
\text { - }\end{array}$ \\
\hline Subcontractors & $\begin{array}{l}\text { - } \text { Absorptive capacity } \\
\text { - Scope of knowledge gap with foreign firms } \\
\text { - Quality of communication with foreign firms } \\
\text { - Quality of interpersonal relationships with foreign managers } \\
\text { - } \quad \text { Duality of foreign supervision of business relationship with foreign contractor }\end{array}$ \\
\hline Suppliers & $\begin{array}{l}\text { - } \text { Absorptive capacity } \\
\text { - Scope of knowledge gap with foreign firms } \\
\text { - Quality of communication with foreign firms } \\
\text { - } \text { Fuality of interpersonal relationships with foreign managers } \\
\text { - } \text { Duration of business relationship with foreign contractor }\end{array}$ \\
\hline Competitors & $\begin{array}{l}\text { - Absorptive capacity } \\
\text { - Scope of knowledge gap with foreign firms } \\
\text { - } \text { Appropriateness of foreign managerial knowledge } \\
\text { - } \text { Poaching capacity } \\
\text { Structural constraints (access to capital) }\end{array}$ \\
\hline Consultancies & $\begin{array}{l}\text { - } \text { Absorptive capacity } \\
\text { - } \text { Quality of communication with foreign firms } \\
\text { - Quality of interpersonal relationships with foreign managers } \\
\text { - Poaching capacity } \\
\text { - Structural constraints (access to capital) }\end{array}$ \\
\hline
\end{tabular}

\section{Chinese construction companies and managerial knowledge spillovers}

The presence of Chinese contractors in Ghana is a controversial topic, as is the broader Chinese presence in Africa. Chinese contractors were often criticised by respondents for their (alleged) unwillingness to engage with the Ghanaian society. Government agencies and international development organisations had a more positive perception of Chinese construction firms, possibly because they can see directly the benefits of their price competitiveness.

Three main issues impact managerial knowledge spillovers from Chinese construction 
firms: their vertical integration, which limits local linkages; their lower level of managerial knowledge, which limits the quantity of knowledge that can be passed on; and most importantly all-Chinese management teams, which limits the opportunities for learning-by-doing and mentoring.

\subsection{Local linkages and vertical integration}

Chinese construction firms in Ghana have the reputation to use less local suppliers and subcontractors than other construction firms. Vertical integration has been a common internationalisation strategy for Chinese MNEs to reduce costs and secure markets (Erdener and Shapiro 2005). As price competitiveness is one of the main advantages of Chinese contractors, a vertically-integrated structure makes sense. Indeed, some respondents noted that Chinese contractors tend to subcontract less than their foreign counterparts to manage to keep their costs under control. The language barrier, or a limited knowledge of the local market, could also explain a preference for vertical integration.

A lack of engagement of Chinese contractors with local companies could constitute a major impediment on managerial knowledge spillovers. However, it is extremely difficult to establish with certainty whether Chinese construction companies are indeed using less Ghanaian suppliers and subcontractors than other foreign contractors. Empirical findings from this research suggest this perception of vertically integrated Chinese construction firms might be exaggerated: the three Chinese companies interviewed confirmed working mostly with local subcontractors. The decision to subcontract seemed to be primarily made on price for all foreign contractors, including Chinese ones.

\subsection{Low-performance management practices}

A second issue that might constrain managerial knowledge spillovers in Chinese construction firms could be the lower quality of managerial knowledge available in these firms. This raises the question of the advancement stage of the managerial knowledge of Chinese contractors, in comparison to other foreign contractors.

While measuring managerial knowledge is a difficult endeavour, the qualitative findings of this research suggest that Western and Chinese firms do have distinct management practices. Western firms were generally perceived to be better organised than Chinese ones. Participants from the public sector and international development agencies praised the contract and site management skills of Western contractors, while Chinese ones were for instance criticised for not always having the equipment or experts announced in the contract available at the start of the project. Safety issues - which can be interpreted as a sign of poor management - were often brought up when discussing Chinese construction companies. A Chinese manager acknowledged himself that management was one of the weaknesses of his company. These deficiencies could affect the potential for managerial knowledge spillovers in Chinese construction companies negatively. However, management systems can adapt and evolve quickly: this relative weakness of Chinese 
contractors could soon disappear, at least in some firms. Broad conclusions should therefore be avoided.

\subsection{All-Chinese management teams}

The most systematically observed difference between Chinese and other foreign construction firms is in their ratio of local to foreign employment. Chinese contractors appear to employ a much greater number of expatriates than do other foreign contractors, especially at the managerial level. This was confirmed by all participants, and is coherent with other academic reports on Chinese firms' management practices in Africa (e.g. Li 2007; Haglund 2009; Lee 2009). As employment statistics provided by interviewed firms demonstrate (Tables 4 and 5), the difference between Chinese and non-Chinese firms in terms of ratios of local to foreign employees is significant ${ }^{9}$. Nonetheless, in terms of absolute numbers, Chinese firms do end up employing more local labour than nonChinese firms - their local headcount is higher, which may reflect more labour-intensive technologies and working practices, or indicate that they are simply bigger (data on companies' revenues was not publicly available). These greater numbers of local employees could be favourable to greater knowledge spillovers, as they translate into larger numbers of local employees being exposed to new management practices. The research presented here focuses on knowledge spillovers to local managers, rather than all of the workers: as detailed in section 4.2.1, local managers are the most likely recipients of managerial knowledge transfers, as they are usually better educated and master more professional skills, which makes them better equipped to absorb new managerial knowledge. In this regard, limited local employment at the managerial level constitutes a major impediment to managerial knowledge spillovers from Chinese construction firms through labour mobility or social networks. However, the potential value of managerial knowledge spillovers to local workers, beyond managerial positions, should be kept in mind when exploring these findings - as they would present a more balanced picture of the contribution of Chinese MNEs to knowledge transfers in Africa.

\footnotetext{
${ }^{9}$ These numbers might fluctuate frequently, as employment varies widely depending on on-going projects and their respective advancement stages. It should also be noted that the construction sector employs significant numbers of casual workers which may not be reflected in those numbers, as they do not usually have formal contracts or engagements with the company that employs them. Though these workers may also be able to assimilate some managerial knowledge from foreign companies, these spillovers are bound to be limited by their position in the managerial hierarchy, their low level of education and skills and the fleeting nature of their engagement with the company therefore, the choice was made to limit the focus of the study to formal employees of construction MNEs.
} 
Tab. 4: Employment patterns in selected Chinese construction companies in Ghana

\begin{tabular}{|c|c|c|c|c|}
\hline Company & $\begin{array}{c}\text { Ghanaian } \\
\text { employees }\end{array}$ & Foreign employees & $\begin{array}{c}\text { Ratio foreign/local } \\
\text { employment }\end{array}$ & $\begin{array}{c}\text { Ghanaian } \\
\text { managers? }\end{array}$ \\
CH_A & 1,000 & 200 & $1 / 5$ & No \\
CH_B & 800 & 100 & $1 / 8$ & Yes \\
\hline CH_C & 2,000 & $480(400$ Chinese $)$ & $1 / 4$ & No \\
CH_D & $200 *$ & $100 *$ & $1 / 2 *$ & No* \\
\hline
\end{tabular}

*The data were not collected in a formal interview and are approximative.

Tab. 5: Employment patterns in selected non-Chinese foreign construction companies in Ghana

\begin{tabular}{|c|c|c|c|c|}
\hline Company & $\begin{array}{c}\text { Ghanaian } \\
\text { employees }\end{array}$ & Foreign employees & $\begin{array}{c}\text { Ratio foreign/local } \\
\text { employment }\end{array}$ & $\begin{array}{c}\text { Ghanaian } \\
\text { managers? }\end{array}$ \\
\hline NCH_A & $223^{* *}$ & $4 * *$ & $1 / 55^{* *}$ & Yes (26)** \\
NCH_B & $300-400$ & $3-5$ & $1 / 100$ & Yes \\
\hline NCH_C & $400-800$ & 14 & $1 / 30$ & Yes \\
\hline
\end{tabular}

**The data given were for one project site only, and may not reflect the totality of the company's workforce.

External stakeholders to the construction sector often attributed the absence of local managers in Chinese companies to a desire to keep Ghanaians out of management circles. Some evoked a trust issue, arguing for instance that "[The Chinese] will never let you know how they run things" or that they simply "prefer dealing with their own kind than with the Ghanaians". However, interviews with Chinese contractors revealed two concrete factors impeding on local recruitment at the managerial level.

\section{The language barrier}

The language barrier can be defined as the loss of rhetorical skills (including negotiation, persuasion and motivation) caused by a limited competency in the working language, resulting in difficulties in "achieving and sustaining effective communication and a productive, collaborative relationship" (Harzing and Feely 2008). To limit the effects of the language barrier in the HQ-subsidiary relationship, MNEs with headquarters operating in a "minority language" (i.e. not spoken at the global level, such as Chinese) tend to rely more heavily on expatriates in subsidiaries (Feely and Harzing 2003).

This is the case for Chinese contractors operating in Ghana. To achieve fluid communication with the parent company in China, the top management of the subsidiary needs to be Chinese. But as senior expatriates struggle the most with language, they naturally prefer a middle-management team who also speaks Chinese, which in turn favours Chinese entry-level managers over Ghanaian ones. This results in the exclusion 
of Ghanaians from the management ladder. This is not simply a question of personal preference: linguistic unity leads to more effective communication, resulting in time and economic gains (Bolton and Dewatripont 1994). This is not something that can be solved by the presence of an interpreter. Real-time interpretation reduces the clarity and the spontaneity of exchanges; it is also extremely time-consuming.

Furthermore, the language barrier can cause feelings of exclusion, confusion and frustration (Harzing and Feely 2008). This is a major impediment to trust-building, which could affect knowledge transfers by altering the quality of interpersonal relationships and restricting the opportunities for formal training and informal learning within the firm (Henderson 2005).

\section{The cultural difference}

In addition to linguistic issues, a deeper cultural clash between Chinese and Ghanaians could explain the lack of local managers in Chinese firms. Culture is a blurry concept that can be understood here as "a collective phenomenon ... about shared values and meanings" (Hoecklin 1995:24). Cultural factors are difficult to discuss because people tend to take them for granted (Pun et al. 2000). Indeed, though half of participants cited cultural difference as a barrier to increased local employment in Chinese firms, few were able to give specific examples. Nonetheless, two main points of tension seemed to emerge from cultural conceptions of work and of time.

For instance, while Chinese workers are lauded for their hard-working attitude, Chinese managers complained that their Ghanaian employees did not have the same working efficiency and did not express the same commitment to work. This can be explained by different cultural relations to work, rather than by an intrinsic Chinese capacity to work hard. There is a high work centrality in Chinese culture (Westwood and Lok, 2003). While anthropological studies of the meaning of work in Ghanaian culture are lacking, some studies suggest that it places an emphasis on interpersonal relationships, rather than increased productivity (Dzobo, 1992). Traditionally, work is not supposed to take time on important social, familial and religious activities, which may explain the reluctance to do overtime and weekend work. However, globalisation and the associated capitalistic transformation of the Ghanaian economy may have reduced the prevalence of these traditional values. Ghanaians could simply lack a reason to work hard under Chinese management (wages too low, limited perspectives of professional evolution). Similarly, divergent Chinese and Ghanaian conceptions of time seem to foster mutual misunderstandings. While the Chinese seem attached to a strict, mechanical conception of time, Ghanaians traditionally construct time more flexibly (Mbiti, 1990). This issue hinders effective communication within the company, but also with suppliers and subcontractors, resulting in delayed deliveries and works.

This cultural clash has a direct impact on the decision to employ, or not employ, locals in managerial positions in Chinese construction firms. These cross-cultural misunderstandings add to the language barrier to prevent the emergence of trust relationships. Previous research has emphasised repeatedly the role of culture in creating 
trust (Doney et al. 1998; Joynt and Warner 2002; Yuki et al. 2005; Gelfand et al. 2007). Trust is especially necessary in uncertain legal environments, such as developing countries', to act as an additional safeguard to formal contracts (Haglund 2009). In this case, mistrust can explain the Chinese reluctance to include Ghanaians at decisionmaking levels.

\section{Additional factors to consider}

Three further factors can help explain the impact of language and culture on the recruitment of local managers in Chinese construction firms. Firstly, historical events have shaped the current Sino-Ghanaian relationships. In Ghana, British colonialism imported a European model of the capitalist firm which may clash with the Chinese one. In China, the Great Cultural Revolution (1966-1976), which was experienced by the most senior Chinese managers in their teenage years, significantly impacted English-learning opportunities and exposure to foreign influences (Adamson 2004; Hu 2002). Secondly, most Chinese construction firms have only emerged on the international scene over the past decade. This limited international experience means they are not only unfamiliar with local markets but also that they lack examples of best practices in cross-cultural management. Finally, Chinese construction companies do not have a strong economic imperative to hire locally. While Western expatriates come at a very high cost, Chinese expatriates remain relatively cheap. They generally do not migrate with their spouse or family, and can live in very basic conditions. The efficiency gains from having an allChinese management team may therefore outweigh the costs of hiring large numbers of expatriates.

Overall, the absence of local managers constitutes the most stringent impediment to managerial knowledge spillovers from Chinese construction companies. However, this situation could evolve rapidly, as some Chinese contractors develop innovative localisation strategies.

\section{Localisation: a strategy employed to enhance knowledge transfer}

\subsection{An example of localisation in the Ghanaian construction sector}

One of the three Chinese construction companies interviewed in Ghana had initiated a managerial localisation programme, progressively including more Ghanaians in its management team. This was a relatively recent (less than two years) strategy, which came about through the personal drive of the CEO of the company's Ghanaian subsidiary. The localisation programme was inspired by the observation of other successful MNEs, operating in Ghana with a very small number of expatriates. It was part of a move towards a more elaborate management system, with clearly defined positions and formal processes - anticipating a reduction in the number of Chinese expatriates.

The firm seemed to put a strong emphasis on the training of local staff, especially on technical aspects. Locals could be paired with Chinese technical experts over a short-time 
training period, or with a Chinese manager for a more long-term professional development. The firm also organised training sessions in both Ghana and China, tailored to the roles and duties of employees. The company had recently hired a Ghanaian director of Human Resources, which constitutes a strong signal for its commitment to localisation. Cross-cultural issues were addressed in a more informal way. An employee reported that Chinese managers were undertaking serious efforts to understand Ghanaian culture and working practices. Team retreats and end-of-year parties also participated in building a local team spirit. A Chinese manager in the firm reported the change in these terms: "...Chinese people as a whole, they are used to work as they work in China. If they work with other Chinese, they don't need to pay attention to communication and language. We used to think like that. We did not trust the Ghanaians. We didn't think they could do the job as well as we do. But we realised we were wrong".

This firm's localisation strategy achieved positive results. It first resulted in labour cost reductions. Though Chinese expatriates receive lower wages, on average, than Western ones, they remain more expensive than local managers - who do not require return flights, extra accommodation or travel insurance. Secondly, localisation improved communication inside and outside the firm (with employees, suppliers, and clients), boosting productivity. However, the implementation of this localisation programme was also challenging. It involved a global rethinking of the company's management system, and the introduction of adequate monitoring tools. This supposes the mobilisation of the entire management team and important financial and technical resources. Managerial localisation is also a lengthy process, requiring a strong commitment from the firm. Poor English remains an issue, especially in more technical positions such as site engineering. Finally, cross-cultural differences cannot be bridged overnight - a respondent stressed the importance of patience in the localisation process: "[Ghanaians] have a different educational background. ... You need to be patient to work with Ghanaians, to understand what is their culture. ... You need to learn how to deal with the culture".

\subsection{Localisation and managerial knowledge spillovers}

If localisation strategies were to become more common across Chinese MNEs operating in Africa, this could have a substantial impact on managerial knowledge spillovers from these firms. Firstly, by encouraging the use of local human resources, localisation improves the integration of the foreign firm into the host country's economic structures. This means increased interactions with local actors (suppliers and subcontractors especially), which multiplies their opportunities to learn from the foreign firm. Secondly, at the managerial level, localisation is a source of further spillovers by offering local employees specific training, as well as a direct exposure to the management of large projects. Through labour mobility, the most experienced local employees might then transfer these acquired skills further into the domestic economy.

A successful localisation strategy could also improve the conditions for managerial knowledge spillovers by reducing the cultural and linguistic gap between Chinese management teams and their local employees and partners. The introduction of local managers, directly handling relationships with the firm's local workforce and 
stakeholders, is likely to lead to an improvement in communication and interpersonal relationships. This should facilitate the establishment of trust between co-workers, increasing mentorship opportunities and creating a better learning environment, both essential to managerial knowledge spillovers. It is also possible that local managers make better vessels to transfer knowledge to their subordinates and partners.

\subsection{Towards fully localised Chinese construction firms?}

The example of the localising Chinese firm presented in section 6.1 may seem rather unique at this point. However, there are indications that other Chinese contractors are sensitive to the advantages of managerial localisation and are considering taking that step. Another firm interviewed announced that they intended to hire a local project manager, stressing that "local people [were] very helpful to deal with local employees", and yet another had hired a local human resources manager, which could be interpreted as a desire to localise labour sourcing further in the near future. This tendency to localisation is not limited to Ghana. According to the Chinese International Contractors' Association (CHINCA), Sinohydro has announced its intention to start recruiting local managers, with an "ultimate goal of localisation of middle-management staff" (quoted in Chen 2010:23). In Nigeria, the China Civil Engineering Construction Corporation (CCECC) has also received praise for its localisation strategy (Mo, 2010).

Localisation strategies may in fact become a necessity for Chinese construction companies in Africa, for three main reasons: growing economic pressures, rising opportunity costs and corporate social responsibility (CSR) considerations. Firstly, expatriate Chinese managers are more and more expensive compared to local ones. This is due to both the rising wages in continental China and a changing perception of expatriation. According to a Chinese participant, emotional needs are now more carefully considered in an expatriation decision, and Chinese firms therefore have to offer more attractive compensation packages to expatriates, including more frequent return travels. Secondly, as more Chinese contractors are making attempts at managerial localisation, the opportunity cost of not being localised is increasing. With savings realised on labour costs, localised Chinese firms could ultimately be more price-competitive than the traditional model of the Chinese international construction firm. Since managerial localisation requires a more complex management system and improves communication and team work (see sections $6.1 \& 6.2$ ), localised Chinese firms are also likely to be more productive in the long run. Additionally, they could benefit from stronger local linkages, and might for instance be able to negotiate better deals and maintain more productive relationships with their suppliers, subcontractors and clients.

Finally, localisation could become a necessity for Chinese contractors to maintain a good corporate image and develop sustainable business relationships with African countries. Taking the example of Ghana, the poor public perception of Chinese construction companies is often linked to labour issues: Chinese contractors are believed to employ very few Ghanaians and to willingly exclude Ghanaians from management. In the long run, these perceptions can damage the company's activities. For instance, it could lead to absenteeism of local employees, who do not recognise themselves in the firm's corporate 
culture (Buciuniene and Kazlauskaite, 2012), to the inability to attract talented individuals, who do not see any evolution opportunities within the firm (Bhattacharya et al. 2008) or to the loss of potential contracts (Wiig and Kolstad, 2010). Maintaining a good corporate image and gaining the support of local communities will therefore be essential to the long-term sustainability of Chinese investments in Africa (Kabemba, 2010). Furthermore, localisation could help Chinese construction companies tackle other CSR issues, such as the recurrent attacks on their labour standards (e.g. Jauch and Baah, 2009).

\section{$7 \quad$ Conclusions}

\section{Key findings}

This paper discussed the contribution of Chinese direct investments in Africa to local development through managerial knowledge transfer, using a case study of the Ghanaian construction sector. The paper highlighted the key channels and determinants of managerial knowledge spillovers in the construction sector, emphasising the central role of personal interactions in the transmission of managerial knowledge. The paper also questioned the structural constraints bearing on the diffusion of managerial knowledge in the domestic economy, and highlighted the role of institutions in lifting those constraints. This work contributes to a better understanding of Chinese contractors' operations in Africa, joining the burgeoning literature on the topic. Whereas these firms are often regarded to be unwilling to integrate and to hire local labour, empirical findings indicate that they employ most of their unskilled labour locally and seriously consider the issue of managerial localisation. However, Chinese MNEs face constraints that other investors do not face - or at least not with the same intensity: linguistic and cultural distance, fuelled by historical factors, makes local communication and trust-building a difficult endeavour. The absence of strong economic incentives does not encourage them to tackle these issues urgently.

The emergence of managerial localisation strategies in Chinese construction firms is likely to become a pressing matter in the near future. Indeed, managerial localisation will soon become a necessity for Chinese construction companies to remain pricecompetitive, client-oriented and well accepted in local societies - three key elements to ensure their sustainability in Africa. Meanwhile, localisation could benefit FDI-recipient economies by fostering knowledge spillovers, creating local employment and encouraging linkages with domestic firms.

\section{Learning from China, learning from Africa}

Although the transfer of managerial knowledge from Chinese MNEs to the local African construction sector is limited due to linguistic and cultural barriers, it would be a complete misinterpretation of this research to suggest that African governments should privilege other investors. Firstly, Chinese construction companies can contribute to local development in Africa in many more ways than just managerial knowledge spillovers. 
Their price competitiveness and their flexibility could transform infrastructure provision in Africa - and economic growth will not be sustainable without considerable infrastructure development across the continent. Secondly, Chinese contractors have shown great adaptability at the global level. They are more and more aware of CSR issues and their safety and environmental practices seem to be improving quickly (Brautigam, 2011). The development of localisation strategies is yet another proof of this adaptability, and a sign that Chinese management systems are rapidly maturing.

For Africa, the learning potential from Chinese firms is therefore very real. Unlike most Western firms operating in Africa, Chinese construction firms have had the recent experience of a rapid build-up of capacity in a developing country context. Domestic African firms willing to take their business to the next level can certainly draw lessons from that experience. But knowledge-sharing is not a one-way street: just as Africa can learn from China, China may very well learn from its experiences in Africa. Indeed, Chinese firms operating on the continent face challenges unmet on their domestic market. To be successful, they have to take into account higher CSR considerations, accept a more intense public scrutiny and engage with local civil societies (trade unions in particular). Above all, they have to address cross-cultural management issues urgently, and design systems able to integrate the culture and working practices of their local employees. Localisation strategies are a very important step in that direction. Not all Chinese companies in Africa will solve these challenges - but those who do may become global leaders.

\section{Policy implications}

Given the importance of localisation strategies to foster managerial knowledge spillovers, African governments, as well as international development institutions, should aim to develop policies to support these strategies. The first objective of public policy could be to toughen conditions for the permanent employment of foreign nationals. As the Ghanaian case demonstrates, it is still relatively easy to work around foreign employment regulations. Stricter immigration policies, visa policies to foreign expatriates in MNEs in particular, or better enforcement of the existing ones, would push companies to start thinking about localisation. Of course, this should be interpreted flexibly: immigration policies should not deter MNEs from investing, nor should they deprive host countries from valuable foreign expertise.

Restrictions on foreign employment have to be paired with extensive provision of information to foreign firms to facilitate their local recruitment process. Public institutions have a role to play in reducing information asymmetry and ensuring that jobseekers are matched with employers. In Ghana, this could include listings of Ghanaian university programmes and the qualifications of their graduates; information on average local wages for specific positions; and a better framework to foster communication between foreign investors and local job-seekers. Where qualified personnel are not available locally, employment contracts for expatriates should include provisions for skill transfers to a local employee. 
Host country governments could require more managerial training and career development plan for local managers and employees. Governments could also aim to develop support systems for localising foreign firms. Features of the local market, including credentials of local suppliers and subcontractors, should be shared with foreign investors prior to their arrival. Targeted actions could attempt to minimise the cultural clash. This could take the shape of information booklets on local laws and customs, as well as public workshops covering issues related to cross-cultural management. This would provide an open space for investors to voice their concerns, and find answers on how to approach these issues. Finally, as the main clients of the construction sector, governments could praise publicly successful strategies of localisation, highlighting their benefits and labelling them as examples of good CSR. By getting a more accurate understanding of the costs and benefits of localisation, and by learning from other firms' experiences, MNEs might be more likely to localise.

The policy implications of this research are most relevant for Chinese firms investing in Africa, and they are contextually situated within the Ghanaian construction sector. Yet, they are likely to be applicable in other sectors and other countries where Chinese firms are investing massively. They could also bear useful insights for firms from other developing economies interested in investing in Africa. Indian, Malaysian and Brazilian companies are looking more and more towards the continent, and are likely to face similar cultural and linguistic challenges.

\section{Limitations \& further research}

It is important to note that these findings are limited by the scope of the research and the field work undertaken. This study has focused on specific channels of managerial knowledge spillovers, mainly employment of local managers in foreign MNEs, and may have overlooked other channels of transmission, such as the relationships between MNEs and government officials that can be developed in pre-contracts visits or training delivered before and after the handover of "turnkey" projects. As Chinese MNEs work extensively with the public sector on infrastructure projects, these relationships could be significant vectors of knowledge spillovers. Other reservations on the findings of this research include the limited access obtained to private firms (both Chinese and nonChinese), which made it difficult to actually observe and compare management teams in their day-to-day activities. Furthermore, the research has actively focused on potential managerial knowledge spillovers to local managers employed in foreign MNEs, working on the assumption that they are the primary recipients of those knowledge transfers. However, workers at lower levels of the managerial hierarchy could also benefit from exposure to new management practices, especially those related to day-to-day management of human resources, supply chain, quality and security and more globally project management. These workers may later grow into management positions or start their own firm, and the value of their experience within a foreign MNE should not be ignored. This is a point that deserves additional attention, notably when discussing the impact of Chinese MNEs in Africa: as these companies tend to employ greater absolute numbers of local workers (due to more labour-intensive technologies and practices), they could represent a significant source for this type of managerial knowledge spillovers. 
Ultimately, further research is needed to better grasp the opportunities and challenges created by the international expansion of Chinese MNEs in Africa. Some quantitative data collection, possibly over an extended period of time, would be extremely helpful to consider whether Chinese firms are indeed localising their management teams, at what speed and with what results for their productivity. Additionally, a longitudinal qualitative line of research could study in more depth the localisation strategies and cross-cultural management issues of Chinese businesses in Africa and their impact. 


\section{References}

Adamson, Bob. 2004. China's English: a History of English in Chinese Education. HongKong: Hong-Kong University Press.

Alden, Chris, and Martin Davies. 2006. "A Profile of the Operations of Chinese Multinationals in Africa." South African Journal of International Affairs 13 (1): 83-96.

Allix, Mark. 2013. "Developed World 'invests Far More in Africa Than China'." Business Day Live, April 19, sec. African Business. Retrieved from http://www.bdlive.co.za/africa/africanbusiness/2013/04/19/developed-worldinvests-far-more-in-africa-than-china, 21 April 2013.

Ancori, Bernard, Antoine Bureth, and Patrick Cohendet. 2000. "The Economics of Knowledge: The Debate About Codification and Tacit Knowledge." Industrial and Corporate Change 9 (2) (June 1): 255-287.

Ayenagbo, Kossi, Wang Rongcheng, Chen Xueting, Ajibike Omolola Lawani, Tommie Njobvu, and Désiré Bessan. 2012. "Sino-Africa Economic and Trade Relations: Its Impact and Implications on the African Continent." African Journal of Business Management 6 (21): 6420-6427.

Bhattacharya, C. B., Sankar Sen, and Daniel Korschun. 2008. "Using Corporate Social Responsibility to Win the War for Talent." MIT Sloan Management Review, 49 (2): 37 - 44.

Biggeri, Mario, and Marco Sanfilippo. 2009. "Understanding China's Move into Africa: An Empirical Analysis." Journal of Chinese Economic and Business Studies 7 (1): 31-54.

Blomstrom, Magnus, and Ari Kokko. 1998. "Multinational Corporations and Spillovers." Journal of Economic Surveys 12 (3): 247-277.

Bolton, Patrick, and Mathias Dewatripont. 1994. "The Firm as a Communication Network." The Quarterly Journal of Economics 109 (4) (November 1): 809-839.

Brautigam, Deborah. 2011. The dragon's gift: the real story of China in Africa. Oxford: Oxford University Press.

Buciuniene, Ilona, and Ruta Kazlauskaite. 2012. "The Linkage Between HRM, CSR and Performance Outcomes." Baltic Journal of Management 7: 5-24.

Buckley, Peter. J., L. Jeremy Clegg, Adam Cross, Xin Liu, Henry Voss, and Ping Zheng. 2007. "The Determinants of Chinese Outward Foreign Direct Investment." Journal of International Business Studies 38 (4): 499-518.

Burke, Christopher, and Lucy Corkin. 2006. "China's Interest and Activity in Africa's Construction and Infrastructure Sectors". Centre for Chinese Studies, Stellenbosch University.

Chen, Chuan. 2010. "Chinese Participation in Infrastructure Development in Africa: Roles and Impacts." EU-China Policy Dialogues. Retrieved from http://file.euchinapdsf.org/Intranet/PDSF1/CHINES2.PDF, 8 January 2013.

Cheung, Kui-yin, and Ping LIN. 2004. "Spillover Effects of FDI on Innovation in China: Evidence from the Provincial Data." China Economic Review 15 (1): 25-44.

Crespo, Nuno, and Maria Paula Fontoura. 2007. "Determinant Factors of FDI Spilloverswhat Do We Really Know?" World Development 35 (3): 410-425.

Doney, Patricia M., Joseph P. Cannon, and Michael R. Mullen. 1998. "Understanding the 
Influence of National Culture on the Development of Trust." The Academy of Management Review 23 (3): 601-620.

Dunning, John H. 1994. "Re-evaluating the Benefits of Foreign Direct Investment." Transnational Corporations 3 (1): 23-51.

Durham, J. Benson. 2004. "Absorptive Capacity and the Effects of Foreign Direct Investment and Equity Foreign Portfolio Investment on Economic Growth." European Economic Review 48 (2): 285-306.

Dzobo, Noah Komla. 1992. "Values in a Changing Society: Man, Ancestors and God." In Wiredu, K. and K. Gyekye (eds). Person And Community: Ghanaian Philosophical Studies, I: 223-240, Washington, D.C: Council for Research in Values and Philosophy.

Eisenhardt, Kathleen M. 1989. "Building Theories from Case Study Research." Academy of Management Review 14 (4): 532-550.

Erdener, Carolyn, and Daniel M. Shapiro. 2005. "The Internationalization of Chinese Family Enterprises and Dunning's Eclectic MNE Paradigm." Management and Organization Review 1 (3): 411-436.

Falvey, Rod, Neil Foster, and David Greenaway. 2007. "Relative Backwardness, Absorptive Capacity and Knowledge Spillovers.” Economics Letters 97 (3): 230234.

Feely, Alan J., and Anne-Wil Harzing. 2003. "Language Management in Multinational Companies." Cross Cultural Management: An International Journal 10 (2) (June 1): $37-52$.

Findlay, Ronald. 1978. "Relative Backwardness, Direct Foreign Investment, and the Transfer of Technology: A Simple Dynamic Model." The Quarterly Journal of Economics 92 (1): 1-16.

$\mathrm{Fu}$, Xiaolan, Andreas Eisingerich, and Rafael de Hoyes. 2007. "Clusters of Management Practices, Structural Embeddedness and Firm Productivity." University of Oxford TMCD Working Paper Series No. 008. Available at http://www.tmdoxford.org/content/clusters-management-practices-structural-embeddedness-andfirm-productivity-xiaolan-fu-0.

Fu, Xiaolan. 2008. "Foreign Direct Investment, Absorptive Capacity and Regional Innovation Capabilities: Evidence from China." Oxford Development Studies 36 (1): 89-110.

$\mathrm{Fu}$, Xiaolan. 2012a. "Multi-dimensional complementarities and the growth impact of China's direct investment on host countries" University of Oxford, TMCD Working Paper Series No 050. Available at http://www.tmdoxford.org/sites/www.tmd-oxford.org/files/publications/SLPTMD-WP-050.pdf.

$\mathrm{Fu}$, Xiaolan. 2012b. "Foreign Direct Investment and Managerial Knowledge Spillovers Through the Diffusion of Management Practices." Journal of Management Studies 49 (5): 970-999.

$\mathrm{Fu}$, Xiaolan, and Yundan Gong. 2011. "Indigenous and Foreign Innovation Efforts and Drivers of Technological Upgrading: Evidence from China." World Development 39 (7): 1213-1225.

$\mathrm{Fu}$, Xiaolan, Carlo Pietrobelli, and Luc Soete. 2011. "The Role of Foreign Technology and Indigenous Innovation in the Emerging Economies: Technological Change and Catching-up." World Development 39 (7): 1204-1212. 
Gelfand, Michele J., Miriam Erez, and Zeynep Aycan. 2007. "Cross-Cultural Organizational Behavior.” Annual Review of Psychology 58 (1): 479-514.

Girma, Sourafel. 2005. "Absorptive Capacity and Productivity Spillovers from FDI: A Threshold Regression Analysis*." Oxford Bulletin of Economics and Statistics 67 (3): 281-306.

Girma, Sourafel, and Holger Gorg. 2003. "Foreign Direct Investment, Spillovers and Absorptive Capacity: Evidence from Quantile Regressions". GEP Working Paper No 2002/14. SSRN Scholarly Paper ID 410742. Rochester, NY: Social Science Research Network.

Glaser, Barney G., and Anselm L. Strauss. 1967. The discovery of grounded theory: strategies for qualitative research. Chicago: Aldine Pub.

Gorg, Holger, and David Greenaway. 2004. "Much Ado About Nothing? Do Domestic Firms Really Benefit from Foreign Direct Investment?” The World Bank Research Observer 19 (2) (September 1): 171-197.

Gu, Jing. 2009. "China's Private Enterprises in Africa and the Implications for African Development." European Journal of Development Research 21 (4) (September): 570-587.

Haglund, Dan. 2009. "In It for the Long Term? Governance and Learning Among Chinese Investors in Zambia's Copper Sector.” The China Quarterly (199): 627646.

Harzing, Anne-Wil, and Alan J. Feely. 2008. "The Language Barrier and Its Implications for HQ-subsidiary Relationships." Cross Cultural Management: An International Journal 15 (1) (February 8): 49-61.

Henderson, Jane Kassis. 2005. "Language Diversity in International Management Teams." International Studies of Management \& Organization 35 (1): 66-82.

Henley, John, Stefan Kratzsch, Mithat Külür, and Tamer Tandogan. 2008. Foreign Direct Investment from China, India and South Africa in Sub-Saharan Africa: A New or Old Phenomenon? UNU-WIDER Research Paper 24, March 2008. United Nations University (UNU).

Hoecklin, Lisa Adent. 1995. Managing Cultural Differences: Strategies for Competitive Advantage. Economist Intelligence Unit. Addison-Wesley New York.

Mo, Hong'e. 2010. "Chinese Construction Company's Localization Strategy Pays Off in Nigeria." $W w w$ focac.org. August 13. Retrieved from http://www.focac.org/eng/zfgx/t723728.htm, 9 January 2013.

Hu, Guangwei. 2002. "Recent Important Developments in Secondary English-language Teaching in the People's Republic of China." Language, Culture and Curriculum 15 (1): 30-49.

Inkpen, Andrew C., and Eric W. K. Tsang. 2005. "Social Capital, Networks, and Knowledge Transfer." Academy of Management Review 30 (1) (January 1): 146165.

Jauch, Herbert. 2011. "Chinese Investments in Africa: Twenty-First Century Colonialism?" New Labor Forum (Murphy Institute) 20 (2): 48-55.

Jauch, Herbert, and Anthony Yaw Baah. 2009. "Chinese Investments in Africa: A Labour Perspective". African Labour Research Network. Retrieved from http://sask-fibin.directo.fi/@Bin/2e2c2a6177da71094fa961d9de4de50a/1349953805/applicatio n/pdf/298928/China-Africa\%20Report\%202009-final.pdf, 11 October 2012. 
Joynt, Pat, and Malcolm Warner. 2002. Managing Across Cultures: Issues and Perspectives. London: Thomson Learning.

Kabemba, Claude. 2010. "The Dragon Is Not Green Enough: The Potential Environmental Impact of Chinese Investment in the DRC." In Harneit-Sievers, A., S. Marks and S. Naidu (eds). Chinese and African Perspectives on China in Africa: 139-154. Cape Town: Pambazuka Press.

Kaplinsky, Raphael, Dorothy McCormick, and Mike Morris. 2007. The Impact of China on sub-Saharan Africa. Institute of Development Studies, University of Sussex. Retrieved from http://www.ids.ac.uk/files/Wp291.pdf, 19 April 2013.

Kaplinsky, Raphael, and Mike Morris. 2009. "Chinese FDI in Sub-Saharan Africa: Engaging with Large Dragons." European Journal of Development Research 21 (4) (September): 551-569.

Keller, Wolfgang. 2001. "Knowledge Spillovers at the World's Technology Frontier". SSRN Scholarly Paper ID 271703. Rochester, NY: Social Science Research Network.

Kokko, Ari. 1994. "Technology, Market Characteristics, and Spillovers." Journal of Development Economics 43 (2): 279-293.

Lall, Sanjaya. 1980. "Vertical Inter-Firm Linkages in LDCs: an Empirical Study." Oxford Bulletin of Economics and Statistics 42 (3) (August 1): 203-226.

Lall, Sanjaya. 1992. "Technological Capabilities and Industrialization." World Development 20 (2): 165-186.

Lall, Sanjaya, and Paul Streeten. 1977. Foreign investment, transnationals, and developing countries. London: Macmillan.

Lee, Ching Kwan. 2009. "Raw Encounters: Chinese Managers, African Workers and the Politics of Casualization in Africa's Chinese Enclaves." The China Quarterly 199 (1): 647-666.

Li, Anshan. 2007. "China and Africa: Policy and Challenges." China Security 3 (3): 6983.

Mbiti, John S. 1990. African Religions and Philosophy. Oxford: Heinemann Educational Publishers.

MOFCOM (Ministry of Commerce People's Republic of China). 2011. 2010 Statistical Bulletin of China's Outward Foreign Direct Investment. Retrieved from http://english.mofcom.gov.cn/aarticle/statistic/foreigninvestment/201109/2011090 7742320.html, last accessed 12 April 2013.

Moran, Theodore H., Edward Montgomery Graham, and Magnus Blomström. 2005. Does Foreign Direct Investment Promote Development? Washington, DC: Institute for International Economics: Center for Global Development.

Motta, Massimo. 1999. Foreign direct investment and spillovers through workers' mobility. London: Centre for Economic Policy Research.

Moyo, Dambisa. 2012. "Beijing, a Boon for Africa." The New York Times, June 27, sec. Opinion. Retrieved from http://www.nytimes.com/2012/06/28/opinion/beijing-aboon-for-africa.html, 11 October 2012.

Polanyi, Michael. 1967. The Tacit Dimension. London: Routledge \& Kegan Paul.

Powell, Walter W., and Kaisa Snellman. 2004. "The Knowledge Economy." Annual Review of Sociology 30 (January 1): 199-220.

Pun, Kit-Fai, Kwai-Sang Chin, and Henry Lau. 2000. "A Review of the Chinese Cultural 
Influences on Chinese Enterprise Management." International Journal of Management Reviews 2 (4): 325-338.

Rodriguez-Clare, Andres. 1996. "Multinationals, Linkages, and Economic

Development." American Economic Review 86 (4): 852-73.

Sanfilippo, Marco. 2010. "Chinese FDI to Africa: What Is the Nexus with Foreign

Economic Cooperation?*." African Development Review 22: 599-614.

Sautman, Barry, and Hairong Yan. 2009. "African Perspectives on China-Africa Links." The China Quarterly 199 (1): 728-759.

Smith, Elizabeth A. 2001. "The Role of Tacit and Explicit Knowledge in the Workplace." Journal of Knowledge Management 5 (4) (December 1): 311-321.

Stewart, Frances. 1983. "Macro-policies for Appropriate Technology: An Introductory Classification.” International Labour Review 122 (3): 279-294.

Sutton, John, and Bennet Kpentey. 2012. "An Enterprise Map of Ghana”. London, International Growth Centre.

Tull, Denis M. 2006. "China's Engagement in Africa: Scope, Significance and Consequences." The Journal of Modern African Studies 44 (03) (August 3): 459479.

UN (United Nations). 2002. "Final Outcome of the International Conference on Financing for Development." - Monterrey Consensus, UN Doc. A/CONF/198/ (March 22, 2002).

Van Valen, Marshall. 2012. "Chinese Builders: You Want It; They Can Build It." The Africa Report, July 2012, International Edition.

Vulink, Moniek. 2004. "Technology Transfer in the Construction Industry of Ghana: Human Resource Development Through International Collaboration Between Foreign and Local Contractors in the Greater Accra Region". Msc. Thesis, Technische Universiteit Eindhoven. Retrieved from http://alexandria.tue.nl/extra2/afstvers1/tm/vulink2004.pdf, 2 December 2012.

Wang, Jian-Ye, and Magnus Blomström. 1992. "Foreign Investment and Technology Transfer: A Simple Model." European Economic Review 36 (1): 137-155.

Westwood, Robert, and Peter Lok. 2003. "The Meaning of Work in Chinese Contexts A Comparative Study." International Journal of Cross Cultural Management 3 (2) (August 1): 139-165.

Wiig, Arne, and Ivar Kolstad. 2010. "Multinational Corporations and Host Country Institutions: A Case Study of CSR Activities in Angola." International Business Review 19 (2): 178-190.

Willoughby, Kelvin W. 1990. Technology Choice: A Critique of the Appropriate Technology Movement. London : Intermediate Technology Publications.

Yuki, Masaki, William W. Maddux, Marilynn B. Brewer, and Kosuke Takemura. 2005. "Cross-Cultural Differences in Relationship- and Group-Based Trust." Personality and Social Psychology Bulletin 31 (62) January 1: 48-62.

Zhang, Yan, Haiyang Li, Yu Li, and Li-An Zhou. 2010. "FDI Spillovers in an Emerging Market: The Role of Foreign Firms' Country Origin Diversity and Domestic Firms’ Absorptive Capacity.” Strategic Management Journal 31 (9): 969-989. 